\title{
Production potential, challenges and prospects of dairy cooperatives in Aksum and Adwa Towns, Ethiopia
}

\begin{abstract}
The aim of the study was to assess the current production capacity of dairy cooperatives and availability of processed milk product varieties, identify the challenges and prospects of dairy cooperatives, and evaluate the supply and demand of dairy products. Questionnaire and focus group discussions were principally used to generate the data. SPSS was employed to analysis the data. Most of the cooperative members $(91.4 \%)$ and $(79.3 \%)$ from Meabel and Nigsti Saba cooperatives respectively reported as the milk production potential of dairy cows was low. The focus group discussion revealed that, raw milk is the only dairy product regularly supplied to the local consumers by dairy cooperatives. According to the reports from the members of the two cooperatives, milk marketing was not as such competitive and attractive. The major production and processing problems listed by the sampled cooperative members were lack of milk processing facilities and skills $(88.8 \%)$, insufficient production area (36.7\%), unpredictable marketing system $(57.3 \%)$, lack of water $(71.7 \%)$, and poor milk production potentials of dairy cows $(82.3 \%)$. About $(93.1 \%)$ of respondents from sampled cooperative members expecting the support of milk processing equipments with relevant trainings from government or non-government organization, and then wants to process and supply a variety of processed dairy products. The average amount of milk supplied for market per day per cooperative was 160liters and 40liters for curd/yoghurt. In non-fasting season, Demand is always above the supply. However, during fasting season only 100-120liters of milk and 20-35liters of yoghurt could sell to the consumers out of the supplied amounts. Therefore, urgent solution is required to save surplus milk either in the form of extending a suitable market linkage or fulfilling necessary inputs for processing it into cheese, ghee, and butter.
\end{abstract}

Keywords: dairy products variety, milk-processing, dairy cows productivity, dairy cooperatives, ethiopia
Volume 5 Issue 6 - 2017

\author{
Godadaw Misganaw,' Fishatsion \\ Hailemariam, ' Dawit Mamo,' Seare Tajebe,' \\ Yayesh Nigussie ${ }^{2}$ \\ 'Department of Animal production and technology, Aksum \\ University, Ethiopia \\ ${ }^{2}$ Department of Agricultural economics, Aksum University, \\ Ethiopia
}

Correspondence: Godadaw Misganaw, Aksum University, Department of animal production and technology, Shire, Tigray, Ethiopia,Email godadaw@gmail.com

Received: August 30, 2017| Published:September 25, 2017

\section{Introduction}

Ethiopia is believed to have the largest cattle population in Africa. Despite its huge population, the livestock subsector in the country is less productive in general, and compared to its potential, the direct contribution to the national economy is limited. ${ }^{1}$ Consequently, the national milk production and the overall milk consumption in Ethiopia are very low, even compared with other least developed African countries. ${ }^{2}$

Dairy production, among the sector of livestock production systems, is a critical issue in Ethiopia where livestock and its products are important sources of food and income, and dairying has not been fully exploited and promoted in the country. ${ }^{3}$ Due to the pivotal role that dairy production plays in the economy of the country as well as the enhancement of the nutritional status of the citizens, development of the sector is crucial. To be effective, the efforts to improve the productivity of smallholder dairy production and improve its market orientation needs to be supported and informed by detailed understanding of the current and dynamic conditions of production, marketing, processing and consumption of milk and dairy products. ${ }^{4}$

In general, more than $75 \%$ of the produce milk is absorbed locally for consumption. ${ }^{5}$ However, in the country, milk production, handling, processing, consumption and marketing is traditional and constrained by multiple problems. Moreover, very limited researches were done to identify the handling, processing, and consumption of milk. ${ }^{6}$

Cooperatives play a significant role in ensuring sustainable supply of raw milk to the dairy industry by coordinating the flow of milk from their members and assisting them by supplying the required dairy farm inputs. Emana $\mathrm{B}^{7}$ reported that there are 180 cooperatives engaged in milk production and marketing operating in different parts of the country. However, this number makes only 0.74 percent of the total number of agricultural and non-agricultural cooperatives and 2percent of agricultural-based cooperatives in the country. In order to attract more cooperatives in to the sector for a better enhancement of dairying in the country; improving the profitability of existing dairy cooperatives through supporting, promoting, solving their production limitations and assessing consumers demand has a paramount importance. Hence, exploring and demonstrating the available dairy products in the area and the existing demand for it gives a direction for dairy cooperatives to scale up their production potentials into observed gaps. Therefore, the objective of the study was

i. To assess the current production capacity of dairy cooperatives and variety of processed milk products in the study area,

ii. To identify the challenges and prospects of dairy cooperatives in the study area and

iii. To explore the supply and demand of dairy products in Aksum and Adwa towns 


\section{Materials and methods}

\section{Description of study area}

The study was carried out in central zone of Tigray region, Northern Ethiopia. The altitude of the zone mainly falls within the category of 2000 to 3000 meter above sea level. Large part of the zone receives mean annual rainfall ranging from 400 to $800 \mathrm{~mm}$. The mean monthly maximum and minimum temperature of the zone are $30^{\circ} \mathrm{C}$ and $10^{\circ} \mathrm{C}$, respectively. The zone has the largest human population in the region. The capital city of the zone is Aksum and, Adwa is the next large town within the zone. The specific study sites were Adwa \& Axum towns with 1006 \& 1024kilometers far from Addis Ababa, capital city of Ethiopia, respectively. These two districts were selected purposively because of the existence of unproductive dairy cooperatives, the existence of high dairy products demand due to the high flow of tourists to the area and large human population in the zone. The study was focused on two cooperatives (Meabel and Nigsti Saba dairy cooperatives) and direct dairy products consumers like (Hotels, restaurants and cafeterias) found in Aksum and Adwa towns.

\section{Sampling procedure}

The study was followed random sampling technique to select sampled respondents among the cooperative members in order to make the data representative and minimize errors. It was done on two dairy cooperatives found in Aksum and Adwa towns, and their direct beneficiaries like hotels, restaurants, and cafeterias. Total 64 individuals were randomly selected among the members of the two cooperatives. In addition, about 16 international hotels were also included randomly among available international hotels in Aksum and Adwa towns. However, restaurants and cafeterias were selected purposively because of they have different reputation and standards. Hence, 20 and 25 well-known restaurants and cafeterias respectively were considered in this study.

\section{Data collection and analysis methods}

Semi-structured questionnaire was used to assess general overview of dairy cooperatives, their production constraints, and prospects. The questionnaire was designed in a way to obtain information on milk production capacity of cooperatives and forms of utilization, including varieties of milk products, ways of handling, processing and its marketing system. In addition, the questioner was also design to assess feed types utilized in cooperatives dairy farms and its sources, major production constraints and requirements of the cooperatives. The questioner was also structured to obtain information about the hotels milk products demand, sources of milk products and their purchasing capacities. Alongside with the questioner, group discussions were also held with the sampled members of the cooperatives, hotel managers, and restaurant and cafeterias owners to fill any emerging gaps created during interview. The data obtained from dairy cooperatives and direct dairy products consumers were screened and entered into Microsoft excel for further analysis. Statistical Procedures for Social Sciences (SPSS) was used to generate descriptive statistics like mean, frequency (percentage) and ranges.

\section{Results and discussion}

\section{Overview of cooperatives milk production potential}

Since the study depends on the survey data, it was difficult to measure objectively the milk production potential of the cooperatives in a definite figure. The production potential was assessed subjectively based on the perception of sample dairy cow owners. As indicated from Table 1, most of the cooperative members (91.4\%) and (79.3\%) from Meabel and Nigsti Saba dairy cooperatives respectively reported that, the current milk production potential of the dairy cows was low. The Dairy farmers were highly complaining on the low milk production potential of their cows. It is consistent with the previous study reported by Ruerd Ruben et al. ${ }^{8}$ which says, in central part of Ethiopia the average milk output per cow remains too low for reaching economies of scale in production. As a reason poor production genotype, poor feeding and management system and reoccurrence of disease was reported during focus group discussion. Hence, most of respondents $(90.2 \%)$ believed that milk production capacity at a farm level was not sufficient to fulfill the livelihood requirement of the households. On the other hand, the focus group discussion revealed that the existing dairy products demand in Aksum and Adwa towns did not always met by the current production potential of the cooperatives especially during non-fasting season. Because, demand is always rises due to high population density that can consume dairy products regularly. Roughage feedstuffs were frequently reported as the main feed type utilized in the cooperatives dairy farm. As summarized in Table 1, only (22.9\%) from the total respondents reported as they used some concentrate feeds for their cows along with roughage feeds. The rest proportion of the respondents used different types of roughage feeds throughout the year. As they tried to discussed in the focus group discussion, the reasons are roughage feedstuffs might be easily accessible, produced around the farm and less expensive than concentrate feed stuffs. Therefore, maximizing milk production on the bases of poor quality and less digestible roughages seems impossible. Hence, poor feed takes the lion share for low milk production potential of the dairy cows besides with poor genetics.

A previous study about dairy products marketing system declares that, in Ethiopia, $95 \%$ of the national milk is marketed through informal channels and is unprocessed. ${ }^{9}$ The focus group discussion in the present study found that, marketing system for dairy products produced in the cooperative dairy farms is not as such competitive and attractive. Similarly, the focus group discussion in the present study pointed out that, especially in the fasting season, consumers demand for dairy products is dropped, and cooperatives are being exposed to expenses. It is in agreement with the previous study that states seasonal variations and fasting periods in Ethiopia affect consumption of dairy products. ${ }^{9}$ Because, in Ethiopian Orthodox Christian religion, half of the year is fasting season that followers prevented/ preserved from consumption of animal originated foods. In terms of religion, about $95.5 \%$ of the population of Aksum and Adwa towns is Orthodox Christians. ${ }^{10}$ Hence, this limited demand during fasting season might be contribute its factor for low productivity potential of the cooperatives.

\section{Challenges and prospects of dairy cooperatives}

At the beginning, the cooperatives principally established from local communities who have dairy cows and, few college-graduated youths, which are responsible for coordination and marketing of the inputs and outputs. The principle was collecting the milk from each member of the cooperative by measuring the amount and then distributing it; if there is leftover, processing it (only pasteurizing and making yoghurt in traditional way). As depicted from Table 2, the maximum number of milking cows holding per person was 10 cows and, the minimum was four cows from Maebel and two cows from Nigsti Saba dairy cooperative members. The major problems 
described by the sampled cooperative members during interview and focus group discussions were lack of milk processing facilities and skills, insufficient production area, poor sanitation, unpredictable marketing system, lack of water and fencing materials for farm site, and poor milk production potentials of dairy cows. Similarly, Ruben $\mathrm{R}^{11}$ who reported that differences in breed type hinder incentives for intensification of dairying at the producers' end of supply chain support it. In order to maximize milk production potentials and profitability of the cooperatives, focus group discussion participants pointed two possible ways that evoke urgent action. The first thing was presenting dairy cattle breeds that are more productive and, secondly providing practical oriented trainings could halt the severity of the problems. They believed that the genetic potential of their dairy cows is poor especially for milk production traits. About (26.4\%) of the respondents indicated that breed replacement by other more productive strain/blood group is a typical solution for the low productivity of the cooperatives. However, majority of the respondents $(58.1 \%)$ believed that breed replacement along with practical based training can effectively reduce our expenses and will improve our profitability and productivity (Table 2).

Table I Milk production status and feed types in cooperatives farms (households percentage)

\begin{tabular}{|c|c|c|c|c|c|}
\hline \multirow{2}{*}{$\begin{array}{l}\text { Parameter's } \\
\text { Milk } \\
\text { production } \\
\text { status of the } \\
\text { cows }\end{array}$} & \multicolumn{2}{|c|}{$\begin{array}{l}\text { Meabel milk } \\
\text { cooperatives }\end{array}$} & \multicolumn{2}{|c|}{$\begin{array}{l}\text { Nigsti saba } \\
\text { cooperatives }\end{array}$} & \multirow{2}{*}{$\begin{array}{l}\text { Average } \\
\%\end{array}$} \\
\hline & $N=35$ & $\%$ & $\mathbf{N}=29$ & $\%$ & \\
\hline Low & 32 & 91.4 & 23 & 79.3 & 85.4 \\
\hline Average & 3 & 8.37 & 6 & 20.7 & 14.6 \\
\hline High & 0 & 0 & 0 & 0 & \\
\hline
\end{tabular}

Amount of milk produced in the farm

$\begin{array}{llllll}\text { Sufficient } & 2 & 5.72 & 4 & 13.8 & 9.8 \\ \text { insufficient } & 33 & 94.3 & 25 & 86.2 & 90.2\end{array}$

Raw milk marketing system

$\begin{array}{llllll}\text { Poor } & 21 & 60 & 19 & 65.5 & 62.8 \\ \text { Good } & 14 & 40 & 10 & 34.5 & 37.2\end{array}$

Types of feed used in the

\section{farms}

\begin{tabular}{|c|c|c|c|c|c|}
\hline Straw & 33 & 94.3 & 21 & 72.4 & 83.4 \\
\hline Hay & 28 & 80 & 25 & 86.2 & 83.1 \\
\hline Wheat bran & 14 & 40 & 18 & 62.1 & 51 \\
\hline Stover & 24 & 68.6 & 22 & 75.9 & 72.3 \\
\hline Concentrates & 10 & 28.6 & 5 & 17.2 & 22.9 \\
\hline $\begin{array}{l}\text { Pasture } \\
\text { grazing }\end{array}$ & 35 & 100 & 29 & 100 & 100 \\
\hline \multicolumn{6}{|c|}{ Sources of feed } \\
\hline Their own & 25 & 53.2 & 27 & 56.25 & 54.7 \\
\hline Market & 22 & 46.8 & 21 & 43.75 & 45.3 \\
\hline
\end{tabular}

Table 2 Problems and requirements of cooperatives (household percentage)

\begin{tabular}{|c|c|c|c|c|c|}
\hline \multirow{2}{*}{ Parameter's } & \multicolumn{2}{|c|}{$\begin{array}{l}\text { Meabel milk } \\
\text { cooperatives }\end{array}$} & \multicolumn{2}{|c|}{$\begin{array}{l}\text { Nigsti saba } \\
\text { cooperatives }\end{array}$} & \multirow{2}{*}{$\begin{array}{l}\text { Average } \\
\%\end{array}$} \\
\hline & $(\mathbf{N}=35)$ & $\%$ & $(\mathrm{~N}=29)$ & $\%$ & \\
\hline
\end{tabular}

No. of
milking cows/ I0-Apr $\quad$ I0-Feb
individual's

Reported ways to maximize milk production

$\begin{array}{lccccc}\begin{array}{l}\text { Breed } \\ \text { Replacement }\end{array} & 10 & 28.6 & 7 & 24.1 & 26.4 \\ \begin{array}{l}\text { Training } \\ \text { Breed }\end{array} & 6 & 17.1 & 4 & 13.8 & 15.5 \\ \begin{array}{l}\text { Replacement }+ \\ \text { Training }\end{array} & 19 & 54.3 & 18 & 62.1 & 58.1 \\ & & & & & \end{array}$

Reported problems in the farm/cooperative

\begin{tabular}{|c|c|c|c|c|c|}
\hline $\begin{array}{l}\text { Lack of Milk } \\
\text { processing } \\
\text { Machines }\end{array}$ & 32 & 91.4 & 25 & 86.2 & 88.8 \\
\hline $\begin{array}{l}\text { Insufficient } \\
\text { Production area }\end{array}$ & 16 & 45.7 & 8 & 27.6 & 36.7 \\
\hline $\begin{array}{l}\text { Lack of Water } \\
\text { Availability }\end{array}$ & 26 & 74.3 & 20 & 69 & 71.7 \\
\hline Unpredictable & & & & & \\
\hline $\begin{array}{l}\text { Marketing } \\
\text { System }\end{array}$ & 22 & 62.8 & 15 & 51.7 & 57.3 \\
\hline $\begin{array}{l}\text { Lack of Fence in } \\
\text { the Farm site }\end{array}$ & 30 & 85.7 & 23 & 79.3 & 82.5 \\
\hline $\begin{array}{l}\text { Poor Milk yield } \\
\text { Potential of cows }\end{array}$ & 25 & 71.4 & 27 & 93.1 & 82.3 \\
\hline \multicolumn{6}{|c|}{ Cooperative expectation from Gov. /NGO's } \\
\hline $\begin{array}{l}\text { Suitable Working } \\
\text { area }\end{array}$ & 22 & 62.9 & 17 & 58.6 & 60.8 \\
\hline $\begin{array}{l}\text { Machines for } \\
\text { Milk processing }\end{array}$ & 35 & 100 & 25 & 86.2 & 93.1 \\
\hline $\begin{array}{l}\text { Facilitate Market } \\
\text { linkage }\end{array}$ & 15 & 42.9 & 13 & 44.8 & 43.9 \\
\hline $\begin{array}{l}\text { Purchasing high } \\
\text { Producing cows }\end{array}$ & 32 & 91.4 & 26 & 89.7 & 90.6 \\
\hline $\begin{array}{l}\text { Fencing Material } \\
\text { for farms }\end{array}$ & 17 & 48.6 & 9 & 31 & 39.8 \\
\hline \multicolumn{6}{|l|}{ Provide } \\
\hline $\begin{array}{l}\text { Appropriate } \\
\text { trainings }\end{array}$ & 28 & 80 & 23 & 79.3 & 79.7 \\
\hline \multicolumn{6}{|l|}{ Loan for } \\
\hline $\begin{array}{l}\text { Maximization of } \\
\text { farm }\end{array}$ & 27 & 77.1 & 19 & 65.5 & 71.3 \\
\hline $\begin{array}{l}\text { Development of } \\
\text { Watering point }\end{array}$ & 31 & 88.6 & 17 & 58.6 & 73.6 \\
\hline
\end{tabular}


In order to make cooperatives more profitable and capable to fed their households as well the community, participants listed many prospects that needs the hand of government or NGOs. Currently, the cooperatives are trying to supply dairy products to consumers by their own effort without any technical and scientifically support. As their report, there was no any extension service that motivates and supports them in nearby distance about how to run an effective dairy business. This is supported by Tegegne $\mathrm{A}^{12}$ reported that most cooperatives lack clear vision and goal, are inefficient and ineffective, have limited knowledge and skill in dairy husbandry and dairy business, lack transparency and accountability and tend to be more dependent on support from the public sector and NGOs. Particularly, they had high interest to obtain milk-processing machines in order to save surplus milk from spoilage and lose during fasting season. In addition, processed milk into different type of cheese and butter has high demand in the area, better price, and long shelf life than raw or liquid milk. Almost all of the respondents from sampled cooperative members $(93.1 \%)$ expecting milk processing equipments from government or non-government organization, and then wants to process and supply a variety of milk products. As they indicated in the focus group discussion, their income is limited, purchasing these equipments by themselves become difficult and over their current purchasing capacity. At the same time, about (90.6\%) of the respondents also showed their high interest to have improved cattle breeds as depicted from Table 2. The cows kept by the farmers are less productive and even their exotic blood level is undefined/unknown. Hence, for the future a condition that can fulfill their interests' interims of presenting the recommended level of exotic cattle blood composition and processing equipments are expected from government bodies or any other NGOs. Moreover, the cooperatives also seeks a professional training about farm management and ways of product processing and handling; loan for fulfilling necessary inputs and watering system for the farms were also among the list of cooperatives expectation from concerned body. Presenting/providing suitable working areas, if possible fencing materials for their farm compounds and a suitable market linkage were also reported as the main requests of the cooperatives for anyone who involved in any development activities.

\section{Supply and current prices of milk products in aksum and adwa towns}

The focus group discussion revealed that, raw milk is the only dairy product supplied regularly to the local consumers by Maebel and Nigsti Saba dairy cooperatives throughout the year. In some instance, pasteurized milk and or yoghurt also presented to the market. However, the remaining milk products like cheese, ghee, and butter were not processed and produced by the cooperatives due to lack of necessary equipments and skills for processing it, In contrary to the current study. Ruerd Ruben ${ }^{8}$ reported that dairy cooperatives in central part of Ethiopia processed milk into reduced fat milk, butter, cheese, and yogurt and then directly sold to the consumers. The average price per liter of milk at cooperatives shop was 12.8 Ethiopian Birr (ETB) and 16 ETB for curd/yoghurt (Table 3). The average time to bring the milk to cooperatives collection units was 45 minutes on foot. Transporting milk for this long time on foot in each milking session seems somewhat difficult, tedious, and labor intensive. It is because of inaccessible transport facilities and the weak capacity of the cooperatives to rearrange the conditions by themselves. Hence, transportation is one of the factors that hinder the supply of dairy products to the consumers. It is in line with the previous study that says, in Bhutan supply of dairy products is influenced by a variety of factors including production, transportation, price, and season. ${ }^{13}$ As showed from Table 3, the average amount of milk supplied for market per day per cooperative was 160 liters and 40liters for curd/ yoghurt. Sampled cooperative members reported that, during nonfasting season there is no marketing problem, all dairy products could be sold immediately it reaches at a collection site. However, during fasting season, out of these daily supplied milk and yoghurt, only 100-120liters of milk and 20-35liters of yoghurt can be sold to the consumers. As the difference indicates, there is probability of wastage of milk and yoghurt that considered as expenses for the cooperatives. Therefore, urgent solution is required to save left over milk either in the form of extending a suitable market linkage or fulfilling necessary inputs for processing it into cheese, ghee, and butter that are known by long shelf life. Because, the local consumers still brings these dairy products from Addis Ababa or importers in a high prices (Table 3).

Table 3 Supply and selling price of dairy products at cooperatives shop

\begin{tabular}{|c|c|c|c|c|}
\hline Parameters & Milk & Cheese & Butter & $\begin{array}{l}\text { Curd/ } \\
\text { yoghurt }\end{array}$ \\
\hline $\begin{array}{l}\text { Average Price } \\
\text { per liter }\end{array}$ & 12.8 birr & NA & NA & 16 birr \\
\hline $\begin{array}{l}\text { Average time to } \\
\text { reach market site }\end{array}$ & 45 minutes & - & - & 45 minutes \\
\hline Storage Facilities & Traditional & NA & NA & Traditional \\
\hline $\begin{array}{l}\text { Average supply/ } \\
\text { day/Cooperative }\end{array}$ & 160liters & NA & NA & 40liters \\
\hline $\begin{array}{l}\text { Sold/day/ } \\
\text { Cooperative in } \\
\text { fasting time }\end{array}$ & $\begin{array}{l}100 \\
-120 \text { liters }\end{array}$ & NA & NA & 20-35liters \\
\hline
\end{tabular}

NA, not available; -, not applicable

\section{Demand of liquid milk in Aksum and Adwa towns}

As we know, the product of dairy farms is milk and milk byproducts. This milk also needs a consumer that can generate revenue and then the income will motivate the farm owner for better enhancement. At the same time, this survey tried to assess the daily demand of direct dairy product consumers like hotels, restaurants, and cafeterias. According to the information obtained from hotels and restaurants, the average purchasing price of milk was 12 Ethiopian birr per liter (ETB) and 16 ETB for a liter of curd/yoghurt (Table 4). There is a slight price difference between milk sold to customer hotels and sold from cooperatives shop. Since, hotels had a contractual agreement, the prices for them is slightly lower than the selling price of milk at the shop for any one-time customers. In addition, yoghurt is not always available like milk. Yoghurt is only processed when, the season/day is fasting time, or in a condition at which transporting and delivering fresh milk to consumers become difficult; since the average time to reach market site on foot is 45 minutes (Table 3 ). Other milk by-products were not reported as supplied from local cooperatives and dairy farmers to the hotels and restaurants. The minimum and maximum demand of milk per hotel per day was 10 and 15 liters, for yoghurt 8 and 15 liters respectively (Table 4$)$. The reported average intake of both milk and yoghurt per hotel per day was also varying 5 
to 10liters. Even if private dairy farmers are also involved in supply of dairy products, the hotels, restaurants, and cafeterias daily intake is below their current daily demands. Hence, when we examine the difference between the current daily intake of direct consumers and their daily demands, there is a considerable gap. Around 5liters of milk/yoghurt demand per day per hotel is not filled. This uncovered demand of consumers might be considered as an opportunity to sustain and expand the cooperatives fate. It can be seen as deriving force for the dairy cooperatives to strengthen their full power for a better productivity and profitability (Table 4).

Table 4 Hotels average demand and purchasing price for milk products from cooperatives

\begin{tabular}{lllll}
\hline Parameters & Milk & Cheese & Butter & $\begin{array}{l}\text { Curd/ } \\
\text { yoghurt }\end{array}$ \\
\hline $\begin{array}{l}\text { Average Price per } \\
\text { liter }\end{array}$ & 12 birr & NA & NA & 16 birr \\
$\begin{array}{l}\text { Availability of Dairy } \\
\text { Products }\end{array}$ & Year round & NA & NA & Rarely \\
$\begin{array}{l}\text { Dairy Products } \\
\text { intake/day/hotel }\end{array}$ & $5-1$ Oliters & NA & NA & $5-1$ liters \\
$\begin{array}{l}\text { Dairy Products } \\
\text { demand/day/hotel }\end{array}$ & $10-15$ liters & NA & NA & $\begin{array}{l}8 \\
-15 \text { liters }\end{array}$ \\
\hline
\end{tabular}

NA, not available

\section{Demand of processed dairy products in Aksum and Adwa towns}

At every town Ethiopia, milk is available in a reasonable price when we compared it with cheese and other processed dairy products. Nevertheless, processed milk into different cheese and butter types are not commonly found at anywhere of the country. They are available in a limited amount in only the capital and/or some regional cities of the country. However, there is high demand for processed dairy products in tourist destiny sites like Aksum, Gonder, Lalibela, and so on. It is contrast with the reports of Ruerd Ruben ${ }^{8}$ who stated that consumer demand for improved dairy products is also limited, thus restricting their willingness to purchase higher quality dairy products. Since, Aksum is one of the centers of tourists, different types of processed dairy products are highly demanded. Due to this fact, considerable amounts of processed dairy products were also transported from the center of the country to the Aksum and Adwa towns. Specially, different cheese types are vital to make tourists favorite foods like pizza, burger, and so on. Different cheese types are always transported from Addis Ababa to Central zone of Tigray (Aksum) across 1024km distance. This is because of the lack of processing facilities and skills in the area. The existing dairy cooperatives reported, as they want to process the milk collected in their center during fasting time and supply to the surrounding consumers/hotels. To do this, they sought a training plus support of necessary processing equipments and continual buttress from extension services. Even due to long distance transportation, the prices of cheese types seem costly when we relate it with production site (Addis Ababa) (Table 5).

The focus group discussion revealed that, four types of cheese and two types of butter are regularly transported from Addis Ababa to the area. The highly demanded cheese type by the local hotels was Mozzarella, which cost 150 ETB perkg. The average demand in Aksum and Adwa towns for this type of cheese per week/hotel was $14.5 \mathrm{~kg}$ (Table 5 ). The second type of cheese demanded by local consumers was Roller cheese, which costs 85 ETB perkg. Relatively it is the cheapest cheese type and its average demand of hotels was $5 \mathrm{~kg}$ per week. Provolone and Parnassian cheese types were reported, as they are transported form Addis Ababa to Central zone of Tigray (Aksum) in order to satisfy the demand of local consumers and tourists. As indicated from Table 5 , on average $7.5 \mathrm{~kg}$ of Provolone cheese demanded per week per hotel. At the same time, ghee and local butter were also transported from Addis Ababa to the study sites, when a scarcity and quality matter exists. On average $7.5 \mathrm{~kg}$ of ghee per week per hotel was required especially during non-fasting season. Hence, except milk, yoghurt and a limited local butter the remaining dairy products are supplied from Addis Ababa.

Table 5 Demand and purchasing prices of processed dairy products in Axum town

\begin{tabular}{llll}
\hline $\begin{array}{l}\text { Dairy } \\
\text { products }\end{array}$ & $\begin{array}{l}\text { Market } \\
\text { sources }\end{array}$ & $\begin{array}{l}\text { Current price/unit at } \\
\text { study site }\end{array}$ & $\begin{array}{l}\text { Average } \\
\text { demand } \\
\text { of hotels/ } \\
\text { week }\end{array}$ \\
\hline $\begin{array}{l}\text { Cheese(type) } \\
\text { Mozzarella Cheese }\end{array}$ & $\begin{array}{l}\text { Addis Ababa } \\
\text { Roller Cheese }\end{array} \quad 150 \mathrm{birr} / \mathrm{kg}$ & $14.5 \mathrm{~kg}$ \\
Provolone Cheese & $85 \mathrm{birr} / \mathrm{kg}$ & $5 \mathrm{~kg}$ \\
Parnassian Cheese & $140 \mathrm{birr} / \mathrm{kg}$ & $7.5 \mathrm{~kg}$ \\
Butter(type) & Addis Ababa + locally & $1 \mathrm{~kg}$ \\
Ghee & & $200 \mathrm{birr} / \mathrm{kg}$ & $7.5 \mathrm{~kg}$ \\
Local Butter & & $150 \mathrm{birr} / \mathrm{kg}$ & $2 \mathrm{~kg}$ \\
\hline
\end{tabular}

\section{Conclusion and recommendation}

The current production potential of cooperatives was reported as very low due to poor genetic potentials cows for milk production traits and poor quality feeds. The dairy products varieties supplied by the cooperatives for local consumers are raw milk, curd/yoghurt, and pasteurized milk. Hence, rearranging a condition that the cooperatives can achieve more productive dairy cow breeds is highly recommended.

The identified challenges of cooperatives were lack of milk processing facilities, low initial capacities, insufficient production area, lack of water, unpredictable marketing system, and low production potentials of dairy cows. During the fasting season, milk supply is always greater than demand unlike the non-fasting season. On the other hand, different cheese and butter types have high demand in the area, better price, and long shelf life than liquid milk. Hence, presenting milk-processing technologies with practical based trainings should be expected from government bodies or any other NGOs, and then capable local cooperatives to process surplus milk into cheese/ butter during fasting season. This effort would give a relief for the local communities that are suffering from shortage of dairy products in terms of quality, quantity, and varieties during non-fasting season. Therefore, to satisfy the demand, the existing cooperatives must be empowered through supporting and fulfilling their limitations.

\section{Acknowledgements}

None. 


\section{Conflict of interest}

Author declares that there is no conflict of interest.

\section{References}

1. Kedija Husien. Characterization of milk production system and opportunity for market orientation: A case study of Mieso district, Oromia Region, Ethiopia. Ethiopia: MSc thesis. Haramaya University; 2008.

2. Kassahun Melesse, Fekadu Beyene. Consumption pattern of milk and milk products in Ada'a woreda, East Shoa Zone, central Ethiopia. LRRD. 2009;21(4):2009.

3. Sintayehu Yigrem, Fekadu Beyene, Azage Tegegne, et al. Dairy production, processing and marketing systems of Shashemene-Dilla area, South Ethiopia. Improving Productivity and Market Success of Ethiopian Farmers: Project Working Paper 9. ILRI, Nairobi; 2008.

4. Asfaw Negassa. Improving smallholder farmers marketed supply and market access for dairy products in Arsi Zone, Ethiopia. Nairobi, Kenya: Research Report 21. ILRI (International Livestock Research Institute). 2009. p. 1-109.

5. Getachew Felleke, Gashaw Geda. The Ethiopian Dairy Development Policy: A Draft Policy Document. Ministry of Agriculture, Addis Ababa, Ethiopia; 2001.

6. Fikrineh N, Estifanos T, Tatek W. Microbial quality and chemical composition of raw milk in the Mid-Rift Valley of Ethiopia. AJAR. 2012;7(29):4167-4170.
7. Emana B. Cooperatives: a path to economic and social empowerment in Ethiopia. Coop Africa Working Paper No. 9. International Labour Office (ILO). Dares Salaam, Tanzania; 2009. 44p.

8. Ruerd Ruben, Alemayehu Dekeba, Bekele Birhanu, et al. Quality upgrading in ethiopian dairy value chains: dovetailing upstream and downstream perspectives. Review of Social Economy. 2017:75(3).

9. SNV (Netherlands Development Organisation). Study on Dairy Investment Opportunities in Ethiopia. 2008:1-59.

10. Gebreyesus Teklebrhan, Saini Sunil Kumar. Assessment of heritage interpretation infrastructures and their challenges pertaining to the areas of aksum, adwa and shire of tigray region in ethiopia. IJEMS. 2017;8(2):122-129.

11. Ruben R, Heras J. Social Capital, Governance and Performance of Ethiopian Coffee Cooperatives. APCE. 2012;83(483):463-484.

12. Tegegne A, Gebremedhin B, Hoekstra D, et al. Smallholder dairy production and marketing systems in Ethiopia: IPMS experiences and opportunities for market-oriented development. IPMS (Improving Productivity and Market Success) of Ethiopian Farmers Project Working Paper 31. ILRI. Nairobi,; 2013;1-78 p.

13. Phanchung, Phub Dorji, Thubten Sonam, et al. Smallholder Dairy Farming in Bhutan: Characteristics, Constraints, and Development Opportunities. 2012;1-18 p. 